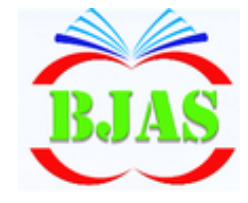

ISSN 1814 - 5868
Available online at http://bajas.edu.iq

https://doi.org/10.37077/25200860.2019.212

College of Agriculture, University of Basrah

Basrah J. Agric. Sci., 32(2): 223-229, 2019
Basrah Journal

of Agricultural

Sciences

E-ISSN: 2520-0860

\title{
The Effects of Foliar Spraying of Folic Acid and Cysteine on Growth, Chemical Composition of Leaves and Green Yield of Faba Bean (Vicia faba L.)
}

\author{
Azhar W.A. Al-Maliky; Awatif N. Jerry* \& Faris I. Obead
}

Department Horticulture and Landscape design, College of Agriculture, University of

\author{
Basrah, Iraq
}

*Corresponding author E-mail: a_n_jerry@yhoo.com

Received 19 September 2019; Accepted 18 November 2019; Available online 20 November 2019

\begin{abstract}
An experiment was conducted during winter growing season of $2018 / 2019$ at Al-Qurnah sub-district, Basrah Governorate to study the effect of foliar spraying of folic acid and amino acid cysteine at different concentrations on growth, Minerals, chlorophyll contents and green yield faba bean (Vicia faba cv. Luz de otono). The study included sixteen treatments Consist of four concentration of folic acid (o,10,20 and 30) mg.L $\mathrm{L}^{-1}$ in combination with four concentrations of Cysteine $(0,10,20$ and 30$) \mathrm{mg} . \mathrm{L}^{-1}$. The results indicated that spraying with folic acid or cysteine significantly increased all vegetative growth characteristics (shoot height, branch number, leaflet number and fresh and dry weight of shoot system per plant), N, P, K, chlorophyll content of leaves and green pod yield/plant and fresh seed yields /plant. Spraying with folic acid at $30 \mathrm{mg} . \mathrm{L}^{-1}$ and cysteine at $30 \mathrm{mg} . \mathrm{L}^{-1}$ gave the greatest values of growth parameters, chlorophyll and yield, whereas $20 \mathrm{mg} . \mathrm{L}^{-1}$ folic acid with $30 \mathrm{mg} . \mathrm{L}^{-1}$ Cysteine was produced the highest values of $\mathrm{N}, \mathrm{P}$ and $\mathrm{K}$ in faba bean leaves as compared with other combination treatments. Control treatment gave the lowest values for growth parameters, chlorophyll, N, P, K and yield.
\end{abstract}

Keywords : Faba bean, folic acid, Cysteine, Growth, yield.

\section{Introduction}

Faba bean (Vicia faba L.) is the fourth most important pulse crop in the world after dry bean, dry peas, and chickpeas. It is considered as the major crop in many countries. This importance is due to its rich protein content of 24-33\% and good source energy (Winch, 2006). In addition, it contributes to soil fertility through biological nitrogen fixation (Igwilo,1982).

Due to the importance of this crop, the need to increase its productivity was one of the main (spur) motives for the use of bio- stimulants such as vitamins and amino acids, including folic acid and amino acid cysteine. Folic acid ( vitamin B9) is a central cofactor for one-carbon transfer reactions which are involved in many cellular reactions such as synthesis of purines, metabolism of amino acids, a glycine to serine conversion, synthesis of methionine and the formation of lignin, chlorophyll and choline and also in the photorespiration cycle (Hanson \& Roje, 2001; Jabrin et al., 2003). Folic acid has become the most prominent of $\mathrm{B}$ complex vitamins despite its essential biochemical function in 
Al-Maliky et al. / Basrah J. Agric. Sci., 32 (2): 88-94 , 2019.

amino acid metabolism and nucleic acid synthesis (Andrew et al., 2000). Folic acid natural antioxidant (Asensi-Fabado \& MunnéBosch, 2010) and folic acid treatment increases growth and productivity (Stakhova et al., 2000). Farouk et al. (2018) recommended that foliar application of $20 \mathrm{mg} . \mathrm{L}^{-1}$ folic acid can be used to induce the plant growth, yield and seed quality of pea (Pisum sativum L.) plants. Heo et al. (2019) showed that treated Antirrhinum majus plants with folic acid at $25 \mathrm{mg} . \mathrm{L}^{-1}$ promoted growth early and also promoted early flowering.

Cysteine is an $\alpha$-amino acid occupies a central position in plant metabolism because it is a reduced sulfur donor molecule involved in the synthesis of essential biomolecules such as vitamins and co-factors, defense compounds such as glucosinolates and thionins and antioxidants, such as glutathione which plays an important role in plant stress responses (Alvarez et al., 2012) the thiol side chain in cysteine often participates in enzymatic reactions (Romero et al., 2014). El-Awadi \& Abd El Wahed (2012) showed that foliar spraying of the cystiene at $25 \mathrm{mg} . \mathrm{L}^{-}$ 1 significantly promoted the growth, quality and Leaf photosynthetic pigment contents of green onion (Alluim cepa L.).

The objective of this study was to evaluate the effect of folic acid and amino acid cysteine as foliar applications on the growth, chemical composition and yield of faba bean.

\section{Material \& Methods}

The field experiments were carried out during the Winter seasons of 2018/2019 at AlQurnah sub-district / Basrah Governorate to investigate the effect of different levels of folic acid and cysteine and the interaction between them on growth, chemical constituents of leaves and yield of faba bean plants. Physical and chemical proprieties of the soil used in the experiment and water irrigation are presented in table (1). Diammonium phosphate DAP (NP (46: 18) was added before sowing at $140 \mathrm{~kg}$. $\mathrm{Ha}^{-1}$. Faba bean seeds cv. Luz de otono (secured from FITO seed Co., Spanish) were sown at

Table (1): The Soil physic-chemical proprieties and irrigation water in the field.

\begin{tabular}{|c|c|}
\hline \multicolumn{2}{|c|}{ Soil characteristics } \\
\hline Character & Value \\
\hline E.C. $\left(\mathrm{dS} . \mathrm{m}^{-1)}\right.$ & 6.16 \\
\hline $\mathrm{pH}$ & 7.55 \\
\hline Total nitrogen $\left(\mathrm{mg} \cdot \mathrm{kg}^{-1}\right)$ & 56 \\
\hline Phosphorus (mg.kg-1 $)$. & 20.14 \\
\hline Potassium (mg. $\left.\mathrm{kg}^{-1}\right)$ & 18.00 \\
\hline Organic matter (\%) & 1.8 \\
\hline \multicolumn{2}{|c|}{ Soil Texture } \\
\hline Sand $(\%)$ & 2 \\
\hline Silt (\%) & 79 \\
\hline Clay (\%) & 19 \\
\hline Texture Class & silty clay \\
\hline \multicolumn{2}{|c|}{ Irrigation water } \\
\hline E.C. $\left(\mathrm{dS} . \mathrm{m}^{-1)}\right.$ & 3.22 \\
\hline $\mathrm{pH}$ & 7.57 \\
\hline
\end{tabular}


4th October /2018 at one side of the ridge. The experimental land is divided into 48 plots each plot contained one treatment. Plot contained 3 ridges, each 2.4 meters long with $75 \mathrm{~cm}$ wide and hills were spaced at $30 \mathrm{~cm}$ distance, and four seeds were sown in each hill. The plants were thinned to two plants per hill at 20 days after sowing. .All treatment plots received the same amount of total fertilizer urea $46 \% \mathrm{~N}$ at the rate of $120 \mathrm{~kg}$. $\mathrm{Ha}^{-1}$ was added after 30 days from sowing.

The experiment consists of 16 treatments, including of folic acid produced by Actavis company and amino acid cysteine produced by Thomas Baker (Chemicals) each of them were used at four level (control, sprayed with distilled water), 10, 20 and 30) mg.L ${ }^{-1}$, applied after 20, 30 and 40 days from sowing as foliar application. The experiment was made in a randomized complete block design in a factorial experiment with three replicates. Treatments means were compared by using Least Significant Differences (L.S.D.) at the probability of 0.05 .

A random sample of 10 plants was assigned for investigation in each plot, to study the morphological characters at 55 days after sowing.

After 55 days from sowing samples of six random plants were taken from experimental plots to estimate the following characteristics: shoot height $(\mathrm{cm})$, number of Leaflet and branches/ plant, shoot fresh and dry weight/ plant (g), chlorophyll (mg.g $\left.{ }^{-1}\right)$ in fresh leaves according to Zaehringer et al. (1974), the mineral percentage determined in dried leaves, nitrogen and potassium estimated according to Page et al. (1982). Phosphorus estimated according to Murphy \& Riley (1962).The harvests started at 4/2/2019 and lasted until 24/3/2019. At harvest determination green pod and fresh seed yield.plant ${ }^{-1}(\mathrm{~g})$.

\section{Results \& Discussion}

Data presented in table (2) revealed that foliar application of folic acid caused a significant increase on plant height, branches/plant, number of the leaflets and as well as fresh weight and dry weight of plants compared to the control treatment. The maximum increase was obtained in response to $30 \mathrm{mg} . \mathrm{L}^{-1}$ folic acid. The improvement of Plant growth characters as a result of folic acid foliar spray may be due to the positive role of folic in regulating the synthesis of proteins and nucleic acids (Andrew et al., 2000), increasing cell division and expansion, synthesis of natural hormones and chlorophyll (Jabrin et al., 2003) and increases nutrient uptake (Kilic \& Ace, 2016). As well as increasing tolerance against abiotic stress (Poudineh et al., 2015). The contribution of folic in these processes reflected by an increase in the size of the total vegetative growth, which was reflected by an increase of plant weight and accumulation of dry matter.

Foliar application of cysteine resulted in a significant increase in shoot height, number of leaves and branches/plant as well as fresh weight and dry weight of plants compared to the control treatment. The application of cysteine at the rate of $30 \mathrm{mg} . \mathrm{L}^{-1}$ gave the greatest values of growth parameter. The increase of growth characters as a result of cysteine foliar spray may be due to the role of cysteine as a source a source of nitrogen and sulfur major macronutrients essential for plant growth and development or to the vital role of cysteine as an amino acid may play an important role in plant metabolism and protein assimilation which is necessary for cell formation (Rai, 2002) and consequently increase the fresh and dry matter or the sulfur 
Al-Maliky et al. / Basrah J. Agric. Sci., 32 (2): 88-94 , 2019.

Table (2): Effect of foliar application of folic acid and cysteine on some vegetative growth characters of faba bean after $\mathbf{5 5}$ days from sowing.

\begin{tabular}{|c|c|c|c|c|c|c|}
\hline \multicolumn{2}{|c|}{ Treatments } & $\begin{array}{l}\text { Shoot } \\
\text { Height } \\
(\mathrm{cm})\end{array}$ & $\begin{array}{l}\text { No. of } \\
\text { branches/plant }\end{array}$ & $\begin{array}{l}\text { Number } \\
\text { of leaflet } \\
\text { /plant }\end{array}$ & $\begin{array}{l}\text { fresh } \\
\text { weight of } \\
\text { shoot }(\mathrm{g})\end{array}$ & $\begin{array}{l}\text { dry } \\
\text { weight of } \\
\text { shoot }(\mathrm{g})\end{array}$ \\
\hline \multicolumn{7}{|c|}{ Folic acid (mg.L $\left.{ }^{-1}\right)$} \\
\hline \multicolumn{2}{|c|}{0} & 33.22 & 3.75 & 87.33 & 131.8 & 30.46 \\
\hline \multicolumn{2}{|c|}{10} & 33.38 & 4.25 & 101.00 & 181.1 & 41.85 \\
\hline \multicolumn{2}{|c|}{20} & 34.73 & 4.57 & 107.50 & 154.8 & 40.25 \\
\hline \multicolumn{2}{|c|}{30} & 35.30 & 4.77 & 112.59 & 197.2 & 45.18 \\
\hline \multicolumn{2}{|c|}{ LSD 0.05} & 1.65 & 0.61 & 4.79 & 10.5 & 5.04 \\
\hline \multicolumn{7}{|c|}{ Cysteine (mg. $\left.\mathrm{L}^{-1}\right)$} \\
\hline \multicolumn{2}{|c|}{0} & 31.79 & 3.68 & 91.25 & 137.0 & 29.48 \\
\hline \multicolumn{2}{|c|}{10} & 33.17 & 4.14 & 105.08 & 168.7 & 40.83 \\
\hline \multicolumn{2}{|c|}{20} & 35.42 & 4.55 & 100.83 & 161.1 & 40.95 \\
\hline \multicolumn{2}{|c|}{30} & 36.23 & 4.97 & 111.25 & 198.1 & 46.58 \\
\hline \multicolumn{2}{|c|}{ LSD 0.05} & 1.65 & 0.61 & 4.79 & 10.5 & 5.04 \\
\hline $\begin{array}{l}\text { Folic } \\
\text { acid }\end{array}$ & Cysteine & \multicolumn{5}{|c|}{ Folic acid $\times$ Cysteine } \\
\hline \multirow[t]{4}{*}{0} & 0 & 27.53 & 2.55 & 60.67 & 109.0 & 22.83 \\
\hline & 10 & 32.63 & 3.75 & 97.33 & 132.9 & 37.17 \\
\hline & 20 & 35.63 & 4.10 & 92.00 & 122.3 & 26.50 \\
\hline & 30 & 37.07 & 4.61 & 99.33 & 163.0 & 35.33 \\
\hline \multirow[t]{4}{*}{10} & 0 & 32.43 & 4.00 & 97.00 & 166.8 & 35.00 \\
\hline & 10 & 32.67 & 4.10 & 97.67 & 181.2 & 39.58 \\
\hline & 20 & 33.97 & 4.22 & 95.33 & 195.0 & 38.83 \\
\hline & 30 & 34.43 & 4.05 & 114.00 & 181.2 & 54.00 \\
\hline \multirow[t]{4}{*}{20} & 0 & 33.53 & 4.11 & 101.67 & 130.8 & 27.00 \\
\hline & 10 & 33.75 & 4.33 & 11.33 & 145.8 & 46.00 \\
\hline & 20 & 35.90 & 4.55 & 102.33 & 153.8 & 47.33 \\
\hline & 30 & 35.90 & 5.28 & 114.67 & 188.7 & 40.67 \\
\hline \multirow[t]{4}{*}{30} & 0 & 33.70 & 4.05 & 105.67 & 141.2 & 32.67 \\
\hline & 10 & 33.80 & 4.39 & 114.00 & 245.0 & 40.57 \\
\hline & 20 & 36.17 & 5.31 & 113.67 & 173.1 & 51.17 \\
\hline & 30 & 37.53 & 5.33 & 117.00 & 259.4 & 56.33 \\
\hline LSD 0.05 & & 3.29 & 1.22 & 9.58 & 20.1 & 10.08 \\
\hline
\end{tabular}

derived from this amino acid is present in the electron transport system may have increased the rate of photosynthetic metabolism (Romero et al., 2014) thus the use of cysteine may have increased the rate of photosynthesis (Jobe et al., 2019), thereby providing a large amount of photoassimilate for growth.

The interaction between the foliar application of folic acid and Cysteine indicated that plants subjected to foliar application of $30 \mathrm{mg} . \mathrm{L}^{-1}$ folic acid with 30 mg. $\mathrm{L}^{-1}$ cysteine showed the highest plant height, branches.plant ${ }^{-1}$, number of leaflet and as well as fresh weight and dry weight of shoots than the other combination treatments. Data presented in table (3) showed that foliar application of folic acid significantly increased nitrogen, potassium and 
Al-Maliky et al. / Basrah J. Agric. Sci., 32 (2): 88-94 , 2019.

Table (3): Effect of foliar application of folic acid and Cysteine on NPK, chlorophyll in leaves and yield of faba bean.

\begin{tabular}{|c|c|c|c|c|c|c|c|}
\hline \multirow{2}{*}{\multicolumn{2}{|c|}{ Treatments }} & \multicolumn{3}{|c|}{ Microelements } & \multirow{2}{*}{$\begin{array}{l}\text { Total } \\
\text { chlorophyll } \\
\left(\mathrm{mg} . \mathrm{g}^{-1}\right. \\
\text { Fw) }\end{array}$} & \multirow{2}{*}{$\begin{array}{l}\text { Green } \\
\text { pod } \\
\text { yield/ } \\
\text { plant }(\mathrm{g})\end{array}$} & \multirow[b]{2}{*}{$\begin{array}{l}\text { Fresh } \\
\text { seed } \\
\text { yield / } \\
\text { plant } \\
\text { (g) }\end{array}$} \\
\hline & & $\mathrm{N} \%$ & $\mathrm{P} \%$ & $\mathrm{~K} \%$ & & & \\
\hline \multicolumn{8}{|c|}{ Folic acid $\left(\mathrm{mg} . \mathrm{L}^{-1}\right)$} \\
\hline & & 2.534 & 0.240 & 2.470 & 9.19 & 339.3 & 165.5 \\
\hline & & 3.800 & 0.298 & 2.676 & 9.58 & 418.8 & 200.0 \\
\hline & & 4.522 & 0.426 & 2.810 & 10.14 & 453.6 & 251.7 \\
\hline & & 3.961 & 0.416 & 2.744 & 10.38 & 608.8 & 291.0 \\
\hline $\mathrm{LS}$ & 0.05 & 0.059 & 0.002 & 0.024 & 1.14 & 13.5 & 11.3 \\
\hline \multicolumn{8}{|c|}{ Cysteine $\left(\mathrm{mg} . \mathrm{L}^{-1}\right)$} \\
\hline & & 3.530 & 0.322 & 2.568 & 8.72 & 358.5 & 185.9 \\
\hline & & 3.610 & 0.334 & 2.628 & 9.91 & 396.5 & 202.9 \\
\hline & & 3.812 & 0.342 & 2.706 & 10.01 & 492.9 & 233.7 \\
\hline & & 3.864 & 0.384 & 2.798 & 10.64 & 572.5 & 286.0 \\
\hline $\mathrm{LS}$ & 0.05 & 0.059 & 0.002 & 0.024 & 1.14 & 13.5 & 11.3 \\
\hline $\begin{array}{l}\text { Folic } \\
\text { acid }\end{array}$ & Cysteine & \multicolumn{6}{|c|}{ Folic acid $\times$ Cysteine } \\
\hline \multirow[t]{4}{*}{0} & 0 & 2.183 & 0.222 & 2.400 & 7.66 & 225.7 & 117.0 \\
\hline & 10 & 2.653 & 0.242 & 2.474 & 9.33 & 321.7 & 145.5 \\
\hline & 20 & 2.523 & 0.248 & 2.480 & 9.17 & 363.3 & 169.8 \\
\hline & 30 & 2.777 & 0.248 & 2.526 & 10.05 & 446.7 & 229.5 \\
\hline \multirow[t]{4}{*}{10} & 0 & 3.770 & 0.254 & 2.560 & 8.22 & 360.0 & 156.9 \\
\hline & 10 & 3.533 & 0.268 & 2.634 & 9.59 & 381.7 & 169.8 \\
\hline & 20 & 4.273 & 0.270 & 2.686 & 9.84 & 453.3 & 210.7 \\
\hline & 30 & 3.623 & 0.404 & 2.826 & 10.66 & 480.0 & 262.6 \\
\hline \multirow[t]{4}{*}{20} & 0 & 4.330 & 0.41 & 2.680 & 9.37 & 381.7 & 223.3 \\
\hline & 10 & 4.367 & 0.416 & 2.720 & 10.09 & 394.3 & 242.1 \\
\hline & 20 & 4.550 & 0.432 & 2.860 & 10.25 & 508.3 & 252.6 \\
\hline & 30 & 4.840 & 0.448 & 2.980 & 10.86 & 530.0 & 288.9 \\
\hline \multirow[t]{4}{*}{30} & 0 & 3.836 & 0.402 & 2.634 & 9.64 & 466.7 & 245.1 \\
\hline & 10 & 3.887 & 0.412 & 2.686 & 10.64 & 488.3 & 254.2 \\
\hline & 20 & 3.903 & 0.418 & 2.794 & 10.24 & 646.7 & 301.8 \\
\hline & 30 & 4.217 & 0.432 & 2.860 & 11.00 & 833.3 & 362.9 \\
\hline \multicolumn{2}{|c|}{ LSD 0.05} & 0.112 & 0.004 & 0.048 & 2.27 & 26.9 & 22.5 \\
\hline
\end{tabular}

phosphorous percentage in a faba bean leaves as compared with control treatments. 20 mg. $\mathrm{L}^{-1}$ folic acid gave the highest values of $\mathrm{N}$, $\mathrm{P}$ and $\mathrm{K}$. Increase in nitrogen, phosphorus and potassium in leaves treated with folic acid due to the effect of folic acid on enhancing root development and the uptake of water and nutrients (Farouk \& EL-Saidy, 2013; Poudineh et al., 2015). Application of cysteine induced a significant increase of $\mathrm{N}$, $\mathrm{P}, \mathrm{K}$ contents of faba bean leaves compared to untreated controls. $30 \mathrm{mg} . \mathrm{L}^{-1}$ gave the highest values of $\mathrm{N}, \mathrm{P}$ and $\mathrm{K}$. increases in $\mathrm{N}, \mathrm{P}$ and $\mathrm{K}$ treated with cysteine due to cysteine is a source of nitrogen and sulfur which are major macronutrients essential for plant growth and development. 
Al-Maliky et al. / Basrah J. Agric. Sci., 32 (2): 88-94 , 2019.

The interaction between the foliar application of folic acid and cysteine indicated that plants subjected to foliar application of $20 \mathrm{mg} . \mathrm{L}^{-1}$ folic acid in combination with $30 \mathrm{mg} . \mathrm{L}^{-1}$ cysteine produced the highest values of $\mathrm{N}, \mathrm{P}$ and $\mathrm{K}$ in faba bean leaves than the other combination treatments.

Foliar application of folic acid on bean plants induced a significant increase in total chlorophyll contents of faba bean leaves (Table 3) compared with untreated control. The folic acid increased the chlorophyll content in leaves and this may be due to that folic acid induced activation of the biosynthesis of glycine, which is involved in the synthesis of porphyrins and chlorophyll in chloroplast membranes (Stakhova et al., 2000).

Foliar application of cysteine on bean plants induced significant increase in chlorophyll contents of faba bean leaves (Table 3) compared with untreated control. The role of cysteine in increasing total chlorophyll could be due to cysteine is a reduced sulfur donor molecule involved in the synthetic of essential biomolecules such as chlorophyll (Romero et al., 2014).

The interaction between folic acid treatments and cysteine significantly affected by chlorophyll (Table 3) $20 \mathrm{mg} . \mathrm{L}^{-1}$ of folic acid with $30 \mathrm{mg} . \mathrm{L}^{-1}$ cysteine gave the highest values than the other combination treatments.

Data presented in (Table 3) showed that foliar application with folic acid significantly increased green pod yield per plant and fresh seed yield per plant compared to the control treatment. The maximum increase was obtained in response to $30 \mathrm{mg}$. $\mathrm{L}^{-1}$ folic acid.

Foliar application of cysteine results in significant increase of green pod and fresh seed yield per plant compared to the control treatment. $30 \mathrm{mg} . \mathrm{L}^{-1}$ cysteine acid gave the highest values. The improvement of faba bean green pod yield and fresh seed yield by applying folic acid or cysteine could be a reflection of vegetative growth, minerals and chlorophyll which in turn leads to an increase of photosynthetic assimilates production that translocate to the reproductive organs during the maturation stage of the pods and seeds.

The interaction between foliar application folic acid and cysteine indicated that plants subjected to foliar application of $30 \mathrm{mg} . \mathrm{L}^{-1}$ folic acid with $30 \mathrm{mg}$. $\mathrm{L}^{-1}$ Cysteine showed the highest green pod and fresh seed yield per plant than the other combination treatments.

\section{Conclusion}

This study can showed the enhanced effect of folic acid and cysteine on growth, the chemical composition of leaves as well as green yield and the fresh seed of faba bean. $30 \mathrm{mg}$. $\mathrm{L}^{-1}$ of folic acid combined with 30 $\mathrm{mg} . \mathrm{L}^{-1}$ of cysteine could effectively improve the growth and yield of faba bean.

\section{Acknowledgments}

The authors want to thank the Department of Horticulture and Landscape Design, College of Agriculture, University of Basrah for assistance.

\section{References:}

Alvarez, C.; Angeles Bermudez, M.; Romero, L.C.; Gotor, C. \& Garcia, I. (2012). Cysteine homeostasis plays an essential role in plant immunity. New Phyt., 193: 165-177.

Andrew, W.J.; Youngkoo, C.; Chen, X. \& Pandalai, S.G. (2000). Vicissitudes of a vitamin. Recent Res. Dev. Phytochem., 4: 89-98. 
Asensi-Fabado, M.A. \& Munné-Bosch, S. (2010). Vitamins in plants: occurrence, biosynthesis and antioxidant function. Trends Plant Sci., 15: 582-592.

El-Awadi, M.E. \& Abd El Wahed, M.S.A.(2012) Improvement the growth and quality of green Onion (Allium cepa L.) plants by some bioregulators in the new reclaimed area at Nobaria Region, Egypt. New York Sci. J., 5(9): 114-120.

Farouk, S. \& Abdul Qados, A.M.S. (2018). Enhancing seed quality and productivity as well as physio-anatomical responses of pea plants by folic acid and/or hydrogen peroxide application. Sci. HorticAmsterdam, 240: 29-37.

Farouk, S. \& El-Saidy, A.E.A. (2013). Seed invigoration techniques to improve germination and early growth of sunflower cultivars. J. Renewable Agric., 1: 33-38.

Hanson, A.D. \& Roje, J.F. (2011). Onecarbon metabolism in higher plant. Annual Rev. Plant Physiol. Plant Mol. Biol., 52: 119-137.

Heo, K.; Glenys Gibson, G. \& Evans, R. (2019). Effects of bisphenol-A and folic acid on growth, reproductive development, and DNA methylation in snapdragons (Antirrhinum majus). Botany, 97(2): 149160.

Igwilo, N. (1982). Nodulation and Nitrogen accumulation in field beans (Vicia faba L.). J. Agric. Sci. Camb., 98: 269-288.

Jabrin, S.; Ravanel, S.; Gambonnet, B.; Douce, R. \& Rebeille, F. (2003). Onecarbon metabolism in plants. Regulation of tetrahydrofolate synthesis during germination and seedling development. Plant Physiol., 131: 1431-1439.

Jobe, T.O.; Zenzen, I.; Karvansara, P.R. \& Kopriva, S. (2019). Integration of sulfate assimilation with carbon and nitrogen metabolism in transition from $\mathrm{C} 3$ to $\mathrm{C} 4$ photosynthesis. J. Exp. Bot., 70(16): 42114221.

Kilic, S. \& Ace, H.T. (2016). Role of exogenous folic acid in alleviation of morphological and anatomical inhibition on salinity-induced stress in barley. Ital. J. Agron., 11(4): 246-251.

Murphy, T. \& Riley J.R. (1962). A modified single solution method for the determination of phosphate in natural waters. Anal. Chem. Acta, 27: 31-36.

Page, A.L.; Miller, R.H. \& Keeney, D.R. (1982). Methods of Soil Analysis Parts, $2^{\text {nd }}$ ed. Madison, Wisconsin: 1159pp.

Poudineh, Z.; Moghadam, Z.G. \& Mirshekari, S. (2015). Effects of humic acid and folic acid on sunflower under drought stress. Bio. Forum- An Inter. J., 7(1): 451-454.

Rai, V.K. (2002). Role of amino acids in plant responses to stresses. Biol. Plantarum., 45: 481-487.

Romero, L.C.; Aroca, M.Á.; Laureano-Marín, A.M.; Moreno, I.; García, I. \& Gotor, C. (2014). Cysteine and cysteine-related signaling pathways in Arabidopsis thaliana. Mol. Plant, 7(2): 264-276.

Stakhova, L.N.; Stakhov, L.F. \& Ladygin, V.G. (2000). Effect of exogenic folic acid on the yield and amino acid composition of the seeds of Pisum sativum L. and Hordeum vulgare L. Prikl Biokhim Mikrobiol., 36(1): 98-103.

Winch, T. (2006). Growing Food. A Guide to Food Production. Springer: 36pp.

Zaehringer, M.V.; Davis, K.R. \& Dean, L.L. (1974). Persisten green color snap beans Phaseolus vulgaris color-related constituents and quality of cooked fresh beans. J. Amer. Soc. Hort. Sci., 99(1): 8992. 